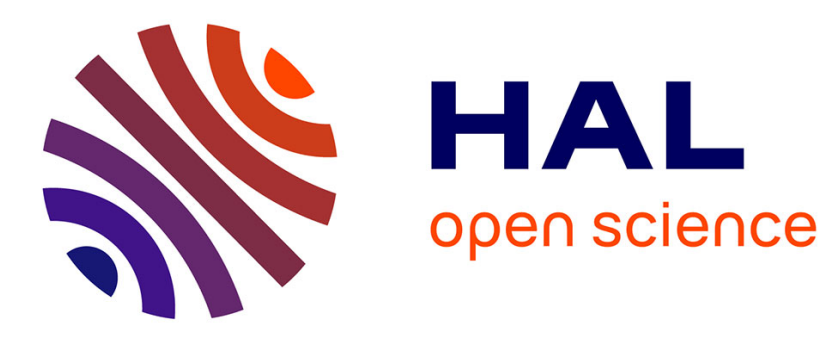

\title{
Dermaseptins as potential antirabies compounds
}

Mohamed Ben Mechlia, Afifa Belaid, Guillaume Castel, Corinne Jallet, Karen

L. Mansfield, Anthony R. Fooks, Khaled Hani, Noël Tordo

\section{To cite this version:}

Mohamed Ben Mechlia, Afifa Belaid, Guillaume Castel, Corinne Jallet, Karen L. Mansfield, et al.. Dermaseptins as potential antirabies compounds. Vaccine, 2019, 37 (33), pp.4694-4700. 10.1016/j.vaccine.2018.01.066 . hal-02626240

\section{HAL Id: hal-02626240 \\ https://hal.inrae.fr/hal-02626240}

Submitted on 23 Sep 2021

HAL is a multi-disciplinary open access archive for the deposit and dissemination of scientific research documents, whether they are published or not. The documents may come from teaching and research institutions in France or abroad, or from public or private research centers.
L'archive ouverte pluridisciplinaire HAL, est destinée au dépôt et à la diffusion de documents scientifiques de niveau recherche, publiés ou non, émanant des établissements d'enseignement et de recherche français ou étrangers, des laboratoires publics ou privés.

\section{(1) (1) $\$$}

Distributed under a Creative Commons Attribution - NonCommercial - NoDerivatives 44.0 


\title{
Dermaseptins as potential antirabies compounds
}

\author{
Mohamed Ben Mechlia ${ }^{\mathrm{a}, \mathrm{b}, *}$, Afifa Belaid $^{\mathrm{b}}$, Guillaume Castel ${ }^{\mathrm{c}}$, Corinne Jallet $^{\mathrm{a}}$, \\ Karen L. Mansfield ${ }^{\mathrm{d}}$, Anthony R. Fooks ${ }^{\mathrm{d}}$, Khaled Hani ${ }^{\mathrm{b}}$, Noël Tordo ${ }^{\mathrm{a}, \mathrm{e}}$ \\ ${ }^{a}$ Unit Antiviral Strategies, Institut Pasteur, 25, rue du Docteur Roux, 75724 Paris Cedex 15, France \\ ${ }^{\mathrm{b}}$ Biochemistry Unit, Medical Faculty, Avenue Mohamed Karoui, 4002 Sousse, Tunisia \\ ' INRA, UMR 1062 CBGP (INRA, IRD, Cirad, Montpellier SupAgro), Campus de Baillarguet, 34988 Montferrier-sur-Lez, France \\ ${ }^{\mathrm{d}}$ Wildlife Zoonosis and Vector-borne Diseases Research Group, Animal and Plant Health Agency (APHA), Addlestone, Surrey KT15 $3 N B$, UK \\ ' Institut Pasteur de Guinée, Université Gamal Abdel Nasser, Conakry, Guinea
}

Over the last 20 years, natural peptides playing a key role in defense mechanisms and innate immunity have been isolated from unicellular organisms. Amphibian skin secretes dermaseptins, 24-34 amino acids in length that have a wide antimicrobial spectrum incorporating yeast, fungi, protozoa, bacteria and enveloped viruses. The anti-rabies virus (RABV) activity of dermaseptins S3 (30aa) and S4 (28aa) from Phyllomedusa sauvagei has been investigated, and further dissected its molecular basis by comparing punctual mutation or deletion of S4 analogues. The results showed that: (1) S4 is more active than S3 against RABV infection, $89 \%$ versus $38 \%$ inhibition at $7.5 \mu \mathrm{M}$; (2) the $5 \mathrm{NH} 2$-aa of S4 are crucial for its inhibitory potential ( $\mathrm{S}_{6-28}$ lost any inhibition) but the $\mathrm{COOH}$ terminus stabilizes the inhibitory potential $\left(\mathrm{S}_{1-16}\right.$ showed only $23 \%$ inhibition at $7.5 \mu \mathrm{M}$ ); (3) there is a correlation between viral inhibition and dermaseptin cytotoxicity, which remains however moderated for BSR cells $(\leq 12 \%$ at $10 \mu \mathrm{M})$. A single mutation in position $4\left(\mathrm{~S} 4_{\mathrm{M} 4 \mathrm{~K}}\right)$ slightly reduced cytotoxicity while keeping its antiviral activity, $97 \%$ at $7.5 \mu \mathrm{M}$. $\mathrm{S} 4$ and $\mathrm{S} 4_{\mathrm{M} 4 \mathrm{~K}}$ showed an antiviral activity in vitro when provided $1 \mathrm{~h}$ after infection. In vivo experiments in mice by intramuscular injection of non-toxic doses of dermaseptin $S 4_{\mathrm{M} 4 \mathrm{~K}} 1 \mathrm{~h}$ post-infection by a lethal dose of RABV at the same site allowed more than 50\% improvement in mice survival. This study highlights the potential interest of dermaseptins as non-expansive alternatives to rabies immunoglobulins for the treatment of rabies that continues to claim about 60,000 human lives per year worldwide, almost exclusively in developing countries.

\section{Introduction}

Rabies encephalitis remains a serious public health problem worldwide, particularly in developing countries from Asia and Africa. The most recent estimates indicate that the number of human cases is approximately 59,000 per year, mostly due to dog bites, which corresponds to 3.7 million disability-adjusted life years (DALYs) and 8.6 billion USD economic losses per year [1]. This alarming death toll is primarily due to either insufficient availability and/or access to the optimal post-exposure prophylaxis (PEP) recommended by the World Health Organization (WHO) [2]. This prophylaxis comprises a series of 4-5 injections of modern vaccines prepared on cell/tissue culture, most commonly through local instillation of anti-rabies immunoglobulins (RIGs) from

* Corresponding author at: Unit Antiviral Strategies, Institut Pasteur, 25, rue du Docteur Roux, 75724 Paris Cedex 15, France.

E-mail address: mchteoui@yahoo.fr (M.B. Mechlia). human (HRIGs) or Equine (ERIGs) origin, either complete or in the form of purified $\mathrm{F}\left(\mathrm{ab}^{\prime}\right)_{2}$ fragments $\left(\mathrm{F}\left(\mathrm{ab}^{\prime}\right)_{2}\right.$-ERIGs) [1]. It confers protection by combining the induction of an active immune response and the immediate neutralization of the viral inoculate by exogenous neutralizing antibodies. However, many of the biological reagents required, particularly HRIGs and ERIGs, are both scarce and costly for developing countries. Consequently, among the 10 millionexposed people receiving the PEP each year, many do not complete the appropriate schedule. Alternative approaches including reduced vaccination regimens, optimized use of antigens, monoclonal antibody cocktails to replace RIGs as well as use of antivirals are being assessed [3-9]. Antivirals are particularly attractive since rabies has a long incubation period (two months in average), during which period no obvious clinical symptoms are observed. However, RABV is neurotropic and not accessible to drugs once within the neurons. Therefore, drugs targeting the early stages of infection, particularly at or close to virus entry into 
epithelial cells, or during the initial replication steps around the biting area, appear promising.

Amphibian skin glands have proven to be a rich source of antimicrobial peptides, with approximately 500 described $[10,11]$. These peptides include dermaseptins, a large family produced by the skin of tree frogs belonging to the genera Phyllomedusa [12-16]. Dermaseptins are linear polycationic peptides, 2434 amino acids in length, adopting an amphipathic $\alpha$-helical structure in apolar solvents [17] as well as in membrane environment. This structure is considered to be the pre-requisite for lipid membrane destabilization and lytic activity [18-22]. During the last ten years, dermaseptins have pioneered the conception of novels antibiotics with a large spectrum of action. They exert a rapid cytolytic activity in vitro against a broad spectrum of pathogenic microorganisms including bacteria [23-25] protozoa [26-28], yeast, parasites and filamentous fungi [29-31]. With regard to viruses, dermaseptins display an antiviral effect against amphibian viruses including channel catfish virus or frog virus 3 (the causal agent of red leg disease) [32], but also against human viruses such as herpes simplex virus type I and II (HSV-1 and 2) [33,34], human immunodeficiency virus type I (HIV-1) [35,36] and human papillomavirus [28].

Although dermaseptins are principally known for their ability to interact with and destabilize lipid membranes [19,37,38], they can also act internally after membrane crossing. One of the most relevant example is the dermaseptin S3, which has been shown to interfere with the DNA integrity of Saccharomyces cerevisiae [29], and can also affect Plasmodium falciparum at the intraerythrocyte level [39]. For enveloped viruses, however, the viral envelope is the preferential target. The dermaseptin S4 and its derivatives have been shown to exert an anti-HIV-1 and anti HSV-1 and 2 activity prior to viral entry, either by disruption of the envelope of the viral particle or by interacting with viral or cell surface molecules responsible for attachment, adsorption and/or fusion [33-35]. As RABV is an enveloped virus, which penetrates the cell via a receptor-mediated recognition [40-42], endocytosis and membrane fusion, it may also represent a potential target for dermaseptins. In this study the anti-rabies activity of dermaseptins S3, (30aa), S4 (28aa) and S4 derivativesboth in vitro and in vivohas been assessed.

\section{Materials and methods}

\subsection{Cells and viruses}

BSR cells, a clone of the Baby Hamster Kidney cells (BHK-21) [43] were cultivated in Dulbecco's modified Eagle's medium (DMEM), Glutamax I (Gibco) supplemented with 5\% heat inactivated foetal calf serum (FCS: Sigma) and $40 \mu \mathrm{g} / \mathrm{ml}$ gentamycin (Sigma). For in vitroinfection experiments, BSR cells were seeded in 96 well plate $\left(3.5 \times 10^{4}\right.$ cells per well), grown for $24 \mathrm{~h}$ at $37^{\circ} \mathrm{C}$ under $5 \% \mathrm{CO}_{2}$ until $70-80 \%$ confluence was achieved, then infected with the RABV Pasteur virus (PV) strain (master suspension $10^{8}$ $\mathrm{UFF} / \mathrm{ml}$ ) at a Multiplicity of Infection of $1(\mathrm{MOI}=1)$. For in vivo infection experiments, the RABV "Challenge Virus Strain" (CVS) strain (master suspension $2.25 \times 10^{8} \mathrm{UFF} / \mathrm{ml}$ ) adapted to mouse brain, was used for infecting mice $1 \mathrm{~h}$ before inoculation with the dermaseptin.

\subsection{Dermaseptins}

Dermaseptins used in this study are analogues to those secreted by the skin of Phylomedusa sauvagei, a south-American tree frog. Two dermaseptins $(\mathrm{S} 3, \mathrm{~S} 4)$ and three S4-derivatives: $\mathrm{S} 4_{\mathrm{M} 4 \mathrm{~K}}$ (Met to Lys substitution in position 4); $\mathrm{S}_{1-16}$ (deletion of the $12 \mathrm{COOH}$ amino-acids) and $\mathrm{S}_{6-28}$ (deletion of the $5 \mathrm{NH} 2$ amino-acids) were compared (Table 1 ). The five dermaseptins were chemically synthesized as described in [35], lyophilized and stored at $-20^{\circ} \mathrm{C}$. Prior to experiments, fresh master solutions were prepared in sterile water, then diluted in Dulbecco's Modified Eagle Medium (DMEM) with Glutamax supplement (Gibco) at the required concentration before addition to the cell supernatant or in phosphate buffered saline (PBS) medium (Gibco) before injection to mice. Concentrations ranging from 1 to $10 \mu \mathrm{M}$ were tested forin vitro experiments. For in vivo experiments in mice, $100 \mu \mathrm{g}$ or $200 \mu \mathrm{g}$ of dermaseptin (purchased from PEPTIDE2.0, USA) were inoculated in the gastrocnemius muscle.

\subsection{Cytotoxicity experiments}

A plate of 96 wells was seeded with BSR cells $\left(4 \times 10^{4}\right.$ cells per well) in DMEM-Glutamax medium supplemented with $5 \%$ of heat inactivated foetal calf serum (Gibco) and $40 \mu \mathrm{g} / \mathrm{ml}$ gentamycin. After $24 \mathrm{~h}$ at $37{ }^{\circ} \mathrm{C}$ under $5 \% \mathrm{CO}_{2}, 50 \mu \mathrm{L}$ of DMEM-Glutamax containing dermaseptin was added to the cell culture supernatant (final dermaseptin concentration ranging from 1 to $10 \mu \mathrm{M}$ ). After $2 \mathrm{~h}$ at $37{ }^{\circ} \mathrm{C}$ under $5 \% \mathrm{CO}_{2}$, the amount of lactate dehydrogenase $(\mathrm{LDH})$ released in the supernatant was measured using the Cytotox $96^{\circledR}$ non-Radioactive Cytotoxicity Assay (Promega). The cytotoxic effect of dermaseptins was quantified as followed: [(LDH in supernatant of treated cells) - (LDH in supernatant of untreated cells)]/ (LDH in lysed untreated cells).

\subsection{Antiviral activity of dermaseptins}

\subsubsection{In vitro}

The antiviral activity of dermaseptins was evaluated pre-, during or post-infection. For all experiments, cells were first cultivated for $24 \mathrm{~h}$ at $37^{\circ} \mathrm{C}$ in DMEM-Glutamax medium (Gibco) supplemented with $5 \%$ of heat inactivated foetal calf serum and $40 \mu \mathrm{g} /$ $\mathrm{ml}$ gentamycin.

For pre-treatment experiments, the cell supernatant was removed, replaced with fresh medium supplemented with dermaseptin at the desired concentration, and incubated for $1 \mathrm{~h}$ at $37{ }^{\circ} \mathrm{C}$ under $5 \% \mathrm{CO}_{2}$. The supernatant was then discarded and cells were infected with the RABV PV strain $(\mathrm{MOI}=1)$ in fresh medium. For co-treatment experiments, cells were infected $(\mathrm{MOI}=1)$ and incubated at $37{ }^{\circ} \mathrm{C}$ in presence of the desired concentration of dermaseptin. For post-infection treatment, cells were infected $(\mathrm{MOI}=$ 1) and incubated for $1 \mathrm{~h}$ at $37^{\circ} \mathrm{C}$. Then the virus inoculum was removed and replaced with fresh medium supplemented with the desired concentration of dermaseptin.

All dermaseptins, i.e. S3, S4, S4 ${ }_{\mathrm{M} 4 \mathrm{~K}}, \mathrm{~S} 4_{1-16}$ and $\mathrm{S} 4_{6-28}$ were evaluated in co-treatment. The two dermaseptins giving the most promising antiviral effect (S4 and $\mathrm{S} 4_{\mathrm{M} 4 \mathrm{~K}}$ ) were additionally evaluated in pre- and post- treatment.

\section{Table 1}

Amino acid sequence of the S3 and S4 dermaseptins and their derivatives. Gaps introduced to improve the similarity n S3 and S4 are indicated by dots. Conserved residues between S3, S4 and S4 derivatives are underlined. Dashes indicate deletions in S4 derivatives. Mutated residue is indicated in bold character. $\mathrm{IC}_{50}$ is the dermaseptine concentration $(\mu \mathrm{M})$ that induces $50 \%$ infection inhibition of BSR cells.

\begin{tabular}{|c|c|c|}
\hline Dermaseptin & Amino acidic sequence & $\mathrm{IC}_{50}$ \\
\hline s3 & ALWKNMLKGIGKLAGKAALGAVKKLVGAES & 8.5 \\
\hline s4 & ALWMTLLKKVLKAAAKAALNAV. . LVGANA & 5.1 \\
\hline S4M4K & ALWKTLLKKVLKAAAKAALNAV. . LVGANA & 5.1 \\
\hline S41-16 & ALWMTLLKKKVLKEAAAK & $>10$ \\
\hline $54_{6-28}$ & - - - - LLKKVLKEAAAKAALNAV. .LVGANA & $>>10$ \\
\hline
\end{tabular}


The anti-RABV effect of pre- co- and post-treatment with dermaseptins was evaluated after $24 \mathrm{~h}$ of infection at $37^{\circ} \mathrm{C}$ in comparison to non-treated cells. The experiments were repeated in duplicate. The modified Rapid Fluorescent Focus Inhibition Test (RFFIT) was used to quantify the infection [44]. Briefly, BSR cells were washed with PBS (Gibco) and fixed with $80 \%$ acetone for $30 \mathrm{~min}$ on ice. Acetone was removed and the plate dried. Cell infection was revealed using a rabbit polyclonal antibody directed against the RABV ribonucleoprotein conjugated to fluorescein (FUJIREBIO Diagnostics Inc.). The antiviral effect of dermaseptins was evaluated by comparing the percentage of infected cellsin mock-treated and treated cells under the same conditions.

Images of infected cells were acquired on an automated spinning disk confocal microscope (Opera QEHS, Perkin Elmer Technologies). Briefly, three fields were acquired per well (above 2000 cells) using a $10 \times$ air objective (NA 0.4) and the following settings: (Ex/Em: $405 \mathrm{~nm} / 450 \mathrm{~nm}$ ) to reveal the cell nuclei stained with DAPI and (Ex/Em $488 \mathrm{~nm} / 540 \mathrm{~nm}$ ) to detect ribonucleoprotein (RNP). The image analysis was performed using Acapella ${ }^{\mathrm{TM}}$ (Perkin Elmer Technologies) using custom developed software. Firstly, the nuclei (DAPI channel) enabled an estimation of the number of cells per well (TN for total nuclei); then a "cell mask" was generated around each nucleus to delimitate each individual cytoplasm; when viral RNP (at least one "green spot") was 'spotted' inside the defined cytoplasm area, the cell was considered "infected" $(\operatorname{InfC})$; the ratio $[\mathrm{InfC} / \mathrm{TN} \times 100]$ corresponded to the percentage of infection per well.

\subsubsection{In vivo}

Animal experiments were performed in compliance with the French animal protection law and in respect of the procedures used at the Institut Pasteur animal facility. SWISS female mice at 6-8 weeks and 25-30 g each (Janvier, France), were divided in experimental groups of eightor ten mice. They were housed with access to food and water ad libitum throughout the experiment. Before virus inoculation, the mice were anesthetized by intra-peritoneal injection of $100 \mu \mathrm{L}$ of a combination of $25 \%$ Imalgene 1000 and 12.5\%Rompun (Centravet ${ }^{\circledR}$ ), diluted in final volume of $1 \times$ PBS $\left(\right.$ Gibco $\left.^{\circledR}\right)$. Mice were inoculated with virus or dermaseptin in the gastrocnemius muscle. Control groups received different doses of the RABV CVS strain or $100 \mu \mathrm{g}$ or $200 \mu \mathrm{g}$ of dermaseptins S4 or S4MAK alone, diluted in DMEM medium. The other groups were first inoculated with the RABV, and $1 \mathrm{~h}$ later, with $100 \mu \mathrm{g}$ or 200 $\mu \mathrm{g}$ of S4 or S4MAK at the same muscle area. The master RABV solution titre was $2.25 \times 10^{8} \mathrm{UFF} / \mathrm{ml}$ (Unit Forming Unit in BSR cells). Virus suspensionwas thawed just before mouse inoculation and diluted in DMEM (Gibco) for adjustment at the desired concentration. Mice were monitored daily over 16 days for appearance and development of clinical signs of increased severity, using the following clinical scoring system: (1) ruffled fur, hunched back; (2) slower movements; (3) twitching in inoculated limb; (4) paralysis. At grade 3-4 (day 6-9 post-inoculation) they were terminated according to ethical humane endpoints by $\mathrm{CO}_{2}$ inhalation.

\section{Results}

\subsection{Dermaseptins are moderately cytotoxic}

We first evaluated the cytotoxicity in BSR cells of dermaseptins S3, S4 and its three derivatives: $\mathrm{S}_{\mathrm{M} 4 \mathrm{~K}}$ with a Met to Lys substitution in position 4 ; $S 4_{1-16}$ with a deletion of 12 amino-acids at the $\mathrm{COOH}$ extremity; $54_{6-28}$ with a deletion of five amino acids at the NH2 extremity (Table 1). The cytotoxicity was assessed by quantifying the amount of lactate dehydrogenase (LDH), a cytoplasmic enzyme released in the medium upon cell lysis, using the Cytotox96 ${ }^{\circledR}$ Non-Radioactive Cytotoxicity Assay (Promega). The level of cytotoxicity was calculated as a percentage of the amount of LDH released after complete lysis of BSR cells. Due to the lack of the LDH stability in the extracellular medium, the cytotoxicity of the dermaseptins was evaluated after $2 \mathrm{~h}$ of incubation with the BSR cells. In the range of concentrations tested $(1-10 \mu \mathrm{M})$ the percentage of cell lysis remained moderated, inferior in all cases to $12 \%$ of the cells (Fig. 1A). However, it was possible to classify the dermaseptins in three groups. $\mathrm{S} 4$ and $\mathrm{S} 4_{\mathrm{M} 4 \mathrm{~K}}$ exhibited the higher cytotoxic effect, ranging from $4-6 \%$ at $3 \mu \mathrm{M}$ to $11-12 \%$ at 10 $\mu \mathrm{M}$. A second group comprising S3 and $\mathrm{S} 4_{1-16}$,demonstrated a lower cytotoxic effect, ranging from $1-2 \%$ at $3 \mu \mathrm{M}$ to $9 / 10 \%$ at 10 $\mu \mathrm{M}$. Finally $\mathrm{S}_{6-28}$ didnot show any cytotoxicity. In summary, the cytotoxicity of S3 and S4 was very moderate and most of the cytotoxicity of S4 is likely due to its five $\mathrm{NH} 2$ amino acids.

\subsection{The first five NH2-amino acids of dermaseptin S4 are essential to the anti-RABV activity}

BSR cells were infected with the PV strain of RABV $(\mathrm{MOI}=1)$ in the presence of increasing concentrations of dermaseptins to evaluate their anti-rabies activity. Twenty-four hours post-infection, the percent of inhibition of RABV infection was measured using the RFFIT method. The percent of BSR cell infection in the presence of dermaseptins was calculated by comparison to mock-treated infected BSR cells (considered 100\% infection). Fig. 1B illustrates the progressive decrease of infected BSR cells (spots of fluorescent RNP) with increasing concentrations of dermaseptin S4. In terms of antiviral activity, the dermaseptins were classified into three groups based on their anti-RABV activity (Fig. 1C). Both S4 and S4 $4_{\mathrm{M} 4 \mathrm{~K}}$ showed the strongest antiviral activity ranking over $85 \%$ from $7.5 \mu \mathrm{M}$ to $10 \mu \mathrm{M}$ and decreasing progressively to $47 \%$ at 5 $\mu \mathrm{M}$ and $14-20 \%$ at $3 \mu \mathrm{M}$. Dermaseptin S3 and S4 ${ }_{1-16}$ were less efficient, inhibiting only $63 \%$ and $34 \%$ of RABV infection at $10 \mu \mathrm{M}$, respectively, while this activity decreased considerably to only $15-11 \%$ at $5 \mu \mathrm{M}$. Finally, dermaseptin $S 4_{6-28}$ did not show any antiviral activity, even at a high concentration. Again, it appeared that the deletion of the first five $\mathrm{NH} 2$ amino acids was deleterious to the anti-RABV activity of the dermaseptin S4, supporting the hypothesis that these residues likely concentrate most of the inhibitory potential, in addition to the cytotoxic effect.

\subsection{The dermaseptins remain active in post-infection protocols}

To investigate the therapeutic potential in vitro of the two dermaseptins demonstrating the more promising antiviral effect (S4 and $\mathrm{S}_{\mathrm{M} 4 \mathrm{~K}}$ ), we further assessed their ability to inhibit RABV when delivered pre- or post-infection. When dermaseptins remained in contact with BSR cells during the $1 \mathrm{~h}$ incubation before removal of the supernatant prior to infection, no significant antiviral effect was observed: only a residual inhibition $(<10 \%)$ was observed at low concentration (0.5-1 $\mu \mathrm{M})$ for S4 (Fig. $2 \mathrm{~A}$ ) and $25 \%$ of inhibition at high concentration for $\mathrm{S} 4_{\mathrm{M} 4 \mathrm{~K}}(4 \mu \mathrm{M})$ (Fig. 2B). However, when the dermaseptins were added $1 \mathrm{~h}$ post infection the antiviral effect was improved, and increased with concentration up to approximately $40 \%$ of inhibition with $\mathrm{S} 4$ at $4 \mu \mathrm{M}$, while $\mathrm{S}_{\mathrm{M} 4 \mathrm{~K}}$ remained limited to $25 \%$ inhibition from 3 to $4 \mu \mathrm{M}$. This post-exposure inhibitory effect is significant and comparable to that obtained when the dermaseptins were present during infection (Fig. 1C).

\subsection{In vivo protective activity of dermaseptin}

For in vivo experiments, 7 groups of 8 mice each were followed during 16 days. Two groups were inoculated in the gastrocnemius muscle with 100 or $200 \mu \mathrm{g}$ of dermaseptin S4 or dermaseptin $\mathrm{S}_{\mathrm{M} 4 \mathrm{~K}}$. The mice continued feeding normally and did not exhibit 


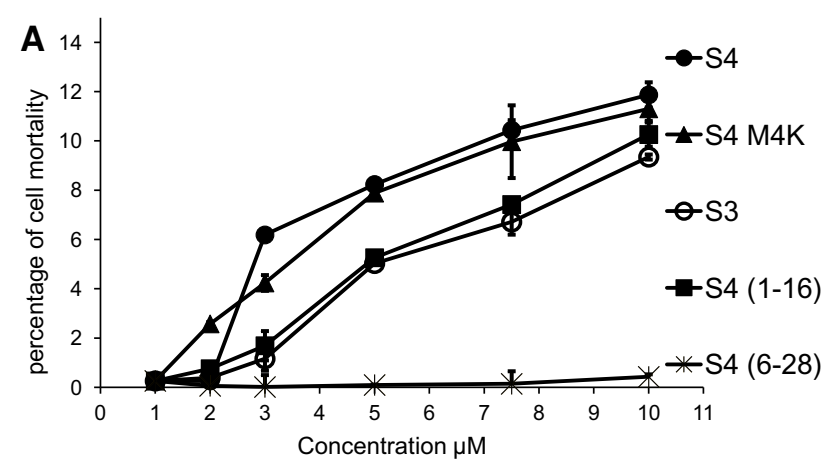

B
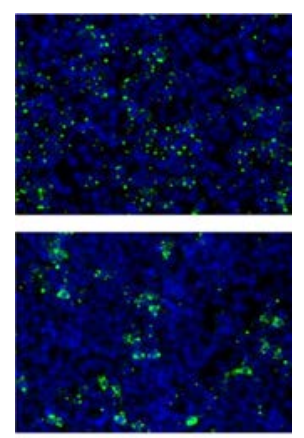

$2 \mu \mathrm{M}$

$4 \mu \mathrm{M}$

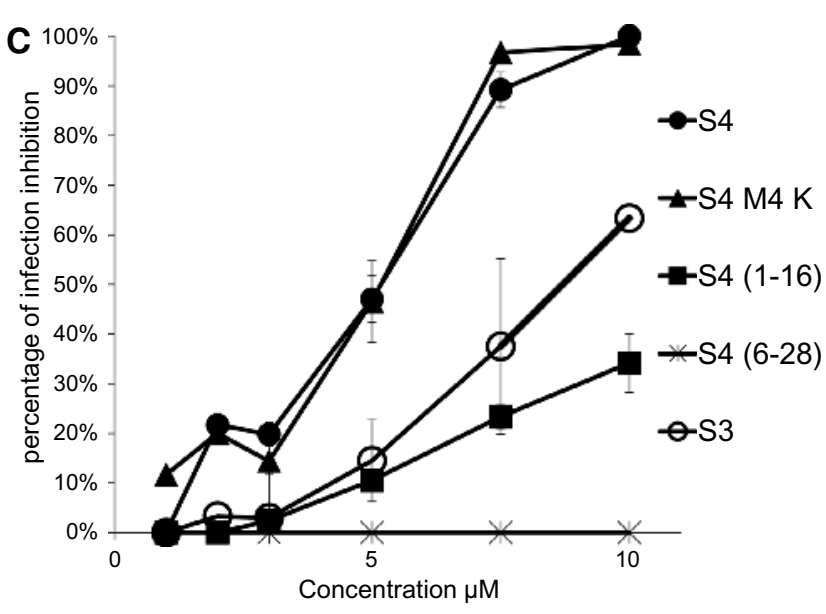

Fig. 1. Cytotoxicity and antiviral activity of dermaseptins. (A) The cell mortality due to dermaseptins was calculated as the percentage of lactate dehydrogenase $(\mathrm{LDH})$ amount released in the extracellular medium by BSR cells treated for $2 \mathrm{~h}$ at the indicated concentration of dermaseptin compared to $100 \%$ released upon complete lysis of the cells. Dermaseptins S4, S4 ${ }_{\mathrm{M} 4 \mathrm{~K}}, \mathrm{~S} 3, \mathrm{~S} 4_{1-16}$ and $\mathrm{S} 4_{6-28}$ were tested at concentrations ranking from 1 to $10 \mu \mathrm{M}$. Results are means of two independent experiments performed in duplicate.(B) BSR cells were infected with RABV PV strain ( $\mathrm{MOI}=1$ ) for $24 \mathrm{~h}$ in presence of the dermaseptins (from 1 to 10 $\mu \mathrm{M})$. The anti-RABV activity was assessed as the percentage of inhibition in comparison to mock-treated cells (100\% infection). The results are means of three independent experiments performed in duplicate. (C) Infection of BSR cells with the RABV PV strain (MOI = 1) was performed in presence of different concentrations of dermaseptins S4. The infection was revealed using a rabbit polyclonal antibody directed against the RABV ribonucleoprotein conjugated to fluorescein.

any impairment in physiology or locomotion (data not shown). An additional group of control mice was challenged with the RABV CVS strain $\left(22.5 \times 10^{5} \mathrm{UFF} /\right.$ mouse $)$. This group demonstrateda sur-
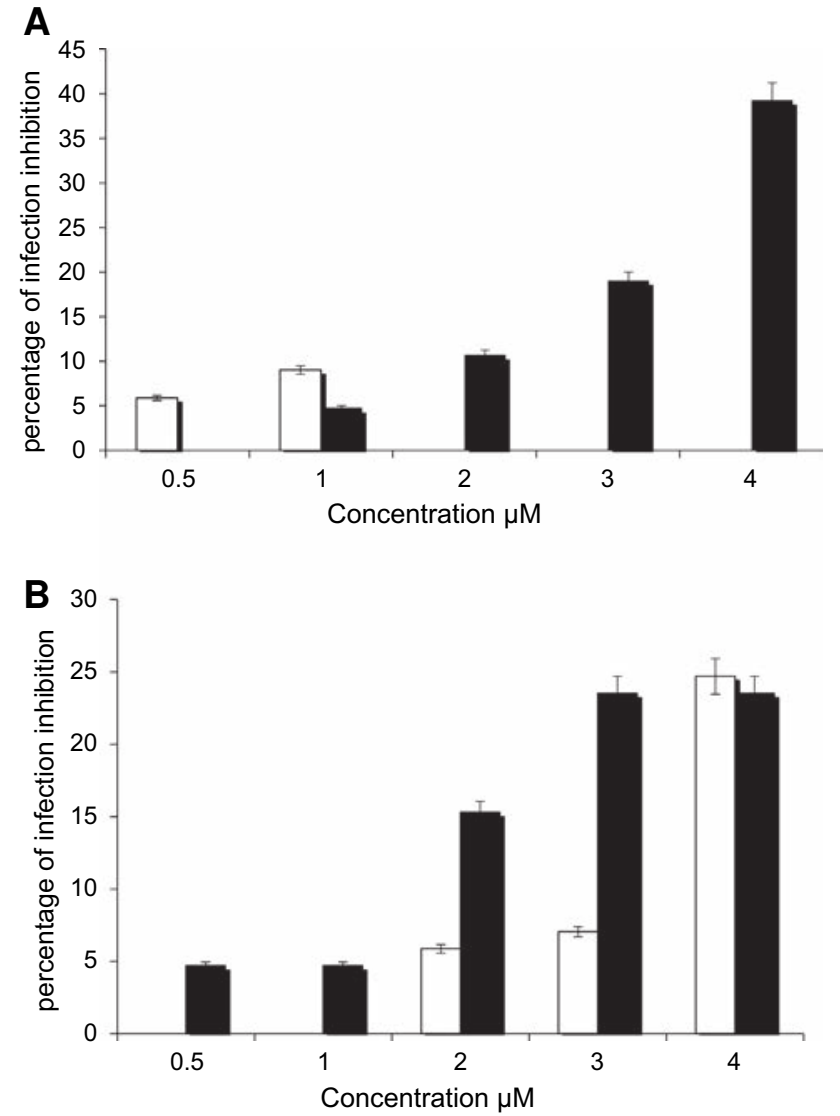

Fig. 2. Antiviral activity of the dermaseptin pre- and post-infection. The antiviral activity of dermaseptin S4 (A) and $\mathrm{S} 4_{\mathrm{M} 4 \mathrm{~K}}$ (B) was assessed when added for $1 \mathrm{~h}$ to culture medium, then removed from the supernatant before infection (white) or when added $1 \mathrm{~h}$ after (black) the infection of BSR cells with RABV (MOI $=1$ ). The results are means of two independent experiments performed in duplicate.

vival rate of only $37.5 \%$ (Fig. 3). When $100 \mu \mathrm{g}$ or $200 \mu \mathrm{g}$ of the dermaseptin $\mathrm{S} 4_{\mathrm{M} 4 \mathrm{~K}}$ were inoculated $1 \mathrm{~h}$ after $\mathrm{RABV}$ infection at the same site, the survival rate was substantially increased to $62.5 \%$ and $75 \%$, respectively. This corresponds to a survival difference of $25 \%$ and $37.5 \%$ compared to the control mice challenged with RABV. Surprisingly, inoculation of $100 \mu \mathrm{g}$ or $200 \mu \mathrm{g}$ of the dermaseptin S4 had no protective effect, and even resulted in a slight decrease in the survival rate to only $12.5 \%$ and $25 \%$ respectively. The mice which succumbed to clinical disease started to show clinical signs by day 6-9 post-infection and were humanely euthanized by day $8-11$. There was no obvious difference in timing to death between the groups, suggesting that the antiviral effect of dermaseptins is most probably due to their RABV neutralizing potency at the early stages of infection.

We further explored the protective effect of $100 \mu \mathrm{g}$ and $200 \mu \mathrm{g}$ of dermaseptin $S 4_{\mathrm{M} 4 \mathrm{~K}}$ in groups of 10 mice infected with different concentrations of RABV CVS strain: $9 \times 10^{5}$ UFF, $22.5 \times 10^{5} \mathrm{UFF}$ and $45 \times 10^{5}$ UFF/animal. Without treatment with the dermaseptin $\mathrm{S} 4_{\mathrm{M} 4 \mathrm{~K}}$, mice demonstrated survival rates of $50 \%, 37.5 \%$ and $0 \%$ respectively (data not shown). Again no mortality was observed in mice that received only dermaseptin $S 4_{\mathrm{M} 4 \mathrm{~K}}$ (data not shown). Interestingly, a dose dependent protective effect was observed when dermaseptin $\mathrm{S}_{\mathrm{M} 4 \mathrm{~K}}$ was administered $1 \mathrm{~h}$ after RABV infection, at the same site. In comparison, $100 \mu \mathrm{g}$ and 200 $\mu \mathrm{g}$ of $S 4_{\mathrm{M} 4 \mathrm{~K}}$ were both able to induce $50 \%$ of survival gain in mice inoculated with $9 \times 10^{5} \mathrm{UFF}$ of RABV (Fig. 4). The survival gain following administration of $100 \mu \mathrm{g}$ of $\mathrm{S} 4_{\mathrm{M} 4 \mathrm{~K}}$ decreased when the viral dose increased to $22.5 \times 10^{5}$ UFF (40\% gain) then $45 \times 10^{5}$ UFF 


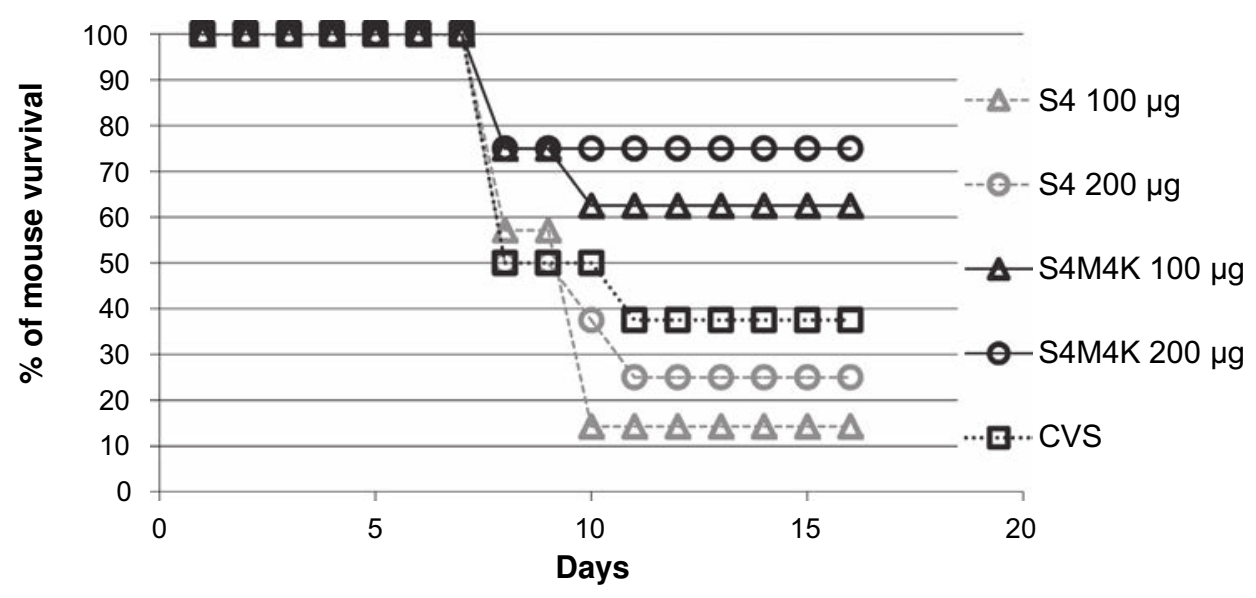

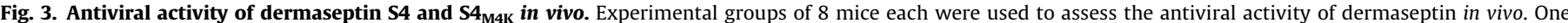

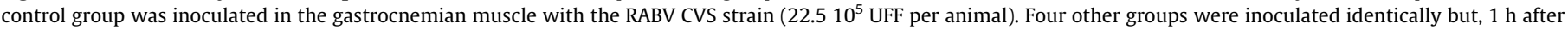
infection, they were again inoculated at the same place with $100 \mu \mathrm{g}$ or $200 \mu \mathrm{g}$ of dermaseptins S4 or S4 $4_{\mathrm{M} 4 \mathrm{~K}}$. Mice were monitored for 16 days.

(20\% gain). In contrast, a dose of $200 \mu \mathrm{g}$ of $S 4_{\mathrm{M} 4 \mathrm{~K}}$ maintained an improvement of $50-60 \%$ of survival gain with the three viral doses. This observation again suggests that the antiviral effect of dermaseptins is due to their RABV neutralizing potency, $200 \mu \mathrm{g}$ being able to titrate higher viral loads.

\section{Discussion}

Antimicrobial peptides (AMPs) are secreted by many organisms including mammals, fishes, amphibians and insects to neutralize pathogens of their microenvironment. Dermaseptins isolated from skin frog display a particularly wide antimicrobial spectrum extending from eukaryotic parasites including protozoa and fungi, up to prokaryotic pathogens such as bacteria and viruses. If their antiviral activity originally targets the frog microenvironment, such as against frog virus 3 or channel catfish virus [32,45], it has the potential to be extended to human enveloped viruses including HSV-1 and 2, HIV-1 and HPV-16 [28,33-35]. In this context, the potential of dermaseptins against RABV infection has been investigated.

Dermaseptin S4 demonstrated a more efficient anti-rabies activity than dermaseptin S3. At a concentration of $7.5 \mu \mathrm{M}$, S4

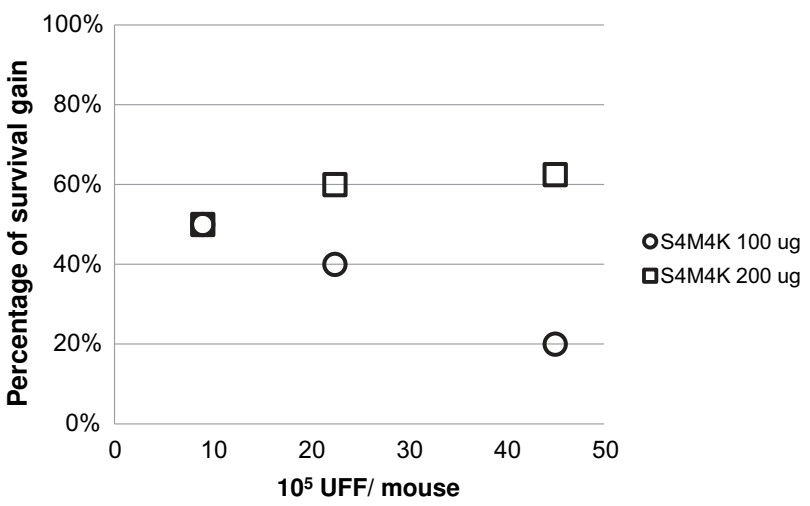

Fig. 4. Assessment of dermaseptin $\mathrm{S} 4_{\mathrm{M} 4 \mathrm{~K}}$ antiviral potential in vivo. Groups of 10 mice were inoculated in the gastrocnemian muscle with increasing doses of the RABV CVS strain: $9 \times 10^{5}$ UFF, $22.5 \times 10^{5}$ UFF and $45 \times 10^{5}$ UFFper animal. For each dose, 1 group was only infected while 2 others were injected 1 h later with $100 \mu \mathrm{g}$ (circles) or $200 \mu \mathrm{g}$ (squares) of dermaseptins S4${ }_{\mathrm{M} 4 \mathrm{~K}}$ at the same place of infection. Mouse survival was followed for 16 days. The graph presents the percent of survival gain due to $S 4_{\mathrm{M} 4 \mathrm{~K}}$ injection compared to mice that received only RABV. inhibited $>85 \%$ of BSR cell infection by RABV compared to only $38 \%$ for S3. In contrast, it was previously shown that S3 is active against the intra-erythrocytic form of Plasmodium falciparum while S4 is not [39]. As S4 and S3 are 60\% identical (Table 1), the aim was to identify the principal residues/regions supporting the antirabies effect. The S4/S3 similarity is spread into three main boxes: box 1 comprises the first three $\mathrm{NH} 2$ residues ALW, the tryptophan being the most conserved residue among the dermaseptins isolated from frog skin secretions; box 2 is restricted to residues LK in position 7-8; box 3 is more spread from position 12 to position 26 (for S4) and 28 (for S3) and not exactly conserved (3 mismatches and 2 gaps). Two deleted analogues of dermaseptin S4 were assessed: $\mathrm{S}_{6-28}$ missing the five $\mathrm{NH} 2$ residues, including the conserved box 1 , demonstrated no anti-rabies activity; $\mathrm{S} 4_{1-16}$ conserving boxes 1 and 2 but missing most of box 3 retained a moderate, but still detectable, anti-rabies activity. This result clearly indicated that the specific anti-rabies activity of dermaseptin S4 is predominantly associated with the first five $\mathrm{NH} 2$ terminal amino-acids, although the $\mathrm{COOH}$ terminus plays an additional role, probably through stabilization of the interaction. Accordingly, the $\mathrm{COOH}$ terminus of dermaseptin S4 has been shown to enhance binding to target membranes [46]. In addition, a deletion analysis of dermaseptin $\mathrm{B} 2$ evidenced that the $\mathrm{COOH}$ end is necessary to allow a flexible helix-hinge-helix structure that facilitates the insertion of the peptide into the membrane [47].

As the first five $\mathrm{NH} 2$ residues of S3 and S4 only differ at position 4 and 5, position 4 of S4 (Met) was mutated in the corresponding residue in the S3 sequence (Lys), thus generating dermaseptin $\mathrm{S} 4_{\mathrm{M} 4 \mathrm{~K}}$. This resulted in a very slight decrease of cytotoxicity in accordance with previous observations that substitution of a hydrophobic by a positively charged amino-acid reduced the hemolytic activity of dermaseptins and enhanced their selectivity for bacterial plasma membranes $[23,48]$. However, $\mathrm{S}_{\mathrm{M}_{\mathrm{MK}}}$ in vitro, retained similar anti-rabies activity to $\mathrm{S} 4$ when given at the time of cell infection: it inhibited approximately $50 \%$ of the infection at $5 \mu \mathrm{M}$ and $>85 \%$ above $7.5 \mu \mathrm{M}$. This is also in agreement with previous data demonstratingthat position 4 of the dermaseptins is relatively permissive to mutations and can vary from basic to Threonine residues without notable effect on their biological activity [28]. Consequently, position 5 (Thr for S4, Asn for S3) could be crucial for the inhibitory activity, ahypothesis that might be further tested with dermaseptin $\mathrm{S} 4_{\mathrm{T} 5 \mathrm{~N}}$.

Taken together, dermaseptin S4 (1-16) appears an appropriate candidate for construction of a novel peptide by introducing substitution or modification for the purpose of enhancing the selective 
activity, while decreasing the cytotoxicity. Indeed, the acyl substitution of $\mathrm{N}$-terminal sequence of a dermaseptin S4 derivative induced selective anti-pseudomonal activity with reduced toxicity towards human red blood cells [46,48-50].

Incubating BSR cells with dermaseptins1h before the infection did not demonstrate a significant inhibitory effect (Fig. 2): while S4 $4_{\mathrm{M} 4 \mathrm{~K}}$, logically acted in a dose dependent manner, S4 was weakly inhibitory at low concentration only, but had no effect at high concentration. It is well known that the concentration of dermaseptins is critical for their specific activity [51-59]. This concentration is crucial to trigger self-association in four to six monomers and to facilitate channel insertion into membranes [47]. It may be speculated that pre-incubation at high concentration of dermaseptin S4 favored stable polymer channels on BSR cell membranes, leaving less monomers free to act on the virus membrane. At lower concentration, monomers of dermaseptin may remain more available to interfere with virus entry.

An interesting observation was that both $\mathrm{S} 4$ and $\mathrm{S} 4_{\mathrm{M} 4 \mathrm{~K}}$ were more efficient at inhibiting RABV infection when added $1 \mathrm{~h}$ after BSR cell infection. This suggests that beside their direct virucidic effect, dermaseptins may also affect the early stages of the intracellular infection, when the virus has been internalized or in the early stages of endocytosis. This result is in accordance with previous studies demonstrating that dermaseptins S3 and derivative of S4 selectively act against intracellular parasites [26,39,60].

Furthermore, the RABV inhibitory potential in mice of dermaseptins S4 and $\mathrm{S} 4_{\mathrm{M} 4 \mathrm{~K}}$ was assessed. Only dermaseptin $\mathrm{S} 4_{\mathrm{M} 4 \mathrm{~K}}$ induced a significant enhancement of the survival rate of infected mice, while dermaseptin S4 did not. Although no detectable toxic changes were observed in cells or tissues upon inoculation with dermaseptin to the mouse gastrocnemius muscle at the doses tested, as already reported with similar concentrations of antibiotics [58], it is not excluded that dermaseptin S4 may be slightly more toxic for animals, as it is in vitro. However, the antiviral activity of the dermaseptin $S 4_{\mathrm{M} 4 \mathrm{~K}}$ appeared promising and functioned in a dose dependent manner: $100 \mu \mathrm{g}$ and $200 \mu \mathrm{g}$, resulted in $62.5 \%$ and $75 \%$ of survival rate, respectively, compared to only $37.5 \%$ observed in mice that only received the virus. This dose dependent protective effect of dermaseptin $\mathrm{S}_{\mathrm{M} 4 \mathrm{~K}}$ was further confirmed against different viral loads, reaching $50-60 \%$ of survival gain compared to mock treated mice. This outlines its ability to titrate and neutralize RABV at the infection site.

\section{Conclusion}

In this study, the anti-rabies activity of dermaseptins S3 and S4 was assessed, and the residues involved in their antiviral effect were identified. In vitro kinetic experiments have shown that dermaseptins can act at the time of infection, but also post-infection, suggesting that their action is not limited to destabilization of the viral membrane but can also interfere with downstream steps of the virus cycle. In vivo studies have shown that $\mathrm{S} 4_{\mathrm{M} 4 \mathrm{~K}}$ is the more efficient dermaseptin, with $50-60 \%$ of survival gain in mice infected $1 \mathrm{~h}$ earlier with a lethal dose of RABV. In the context of RABV infection and PEP, such an early post-infection antiviral effect would be of paramount interest. Indeed, RABV transmission to human mostly occurs through dog (or other rabid animal) bite. The virus replicates locally at the site of bite before reaching the neuron endings and travelling towards the central nervous system through retrograde axoplasmic flow [61]. These early steps of infection are a crucial target for the anti-RABV strategy, and the World Health Organization recommends, in the case of a category III (severe) exposure, to complement post-exposure vaccination with extensive wound cleansing with soap of the area of bite, followed by a local instillation of anti-rabies immunoglobulins. The latter being in dramatic shortage worldwide, a local application of active dermaseptins could substantially contribute to inactivation of the viral particle and possibly to act against the first steps of endocytosis.

\section{Acknowledgements}

This work was supported by the EU grant FP7-60282 Asklepios "Advanced Studies towards Knowledge on Lyssavirus Encephalitis Pathogenesis Improving Options for Survival". Mohamed Chteoui (MC) was recipient of a fellowship of Fondation Mérieux, 17, rue Bourgelat, Lyon. Guillaume Castel (GC) was recipient of fellowships of the University Paris VI of Institut Pasteur. We thank Frédéric Tangy (Unité de Génomiquevirale et vaccination - CNRS URA3015, Institut Pasteur, 25, rue du Docteur Roux, 75724 Paris Cedex 15, France) for critical input throughout the development of the work. The imaging and quantifications have been performed at the Imagopole-CiTech. The Imagopole is part of the France Biolmaging infrastructure supported by the French National Research Agency (ANR-10-INSB-04-01, "Investments for the future" and is gratefully supported by Conseil de la Region Ile-de-France (program Sesame 2007, projet Imagopole, S. Shorte) and by the Fondation Française pour la Recherche Médicale (FRM, Programme Grands Equipements to N. Aulner).

\section{Contributors}

MBM, AB, KH and NT have participated in the conception and design of the study. The experiments have been performed by MBM, CJ and KLM. These data were acquired, analyzed and interpreted by MBM, KLM, ARF and NT. The manuscript was drafted by MBM, GC and NT and was critically revised by AB, KLM, ARF and $\mathrm{KH}$. All authors have approved the final submitted version.

\section{References}

[1] Hampson K, Coudeville L, Lembo T, Sambo M, Kieffer A, Attlan M, et al. Estimating the global burden of endemic canine rabies. PLoS Negl Trop Dis 2015;9:e0003709.

[2] WHO. Rabies fact sheet no. 99; 2015.

[3] Jackson AC, Warrell MJ, Rupprecht CE, Ertl HC, Dietzschold B, O'Reilly M, et al. Management of rabies in humans. Clin Infect Dis 2003:36:60-3.

[4] Willoughby Jr RE, Tieves KS, Hoffman GM, Ghanayem NS, Amlie-Lefond CM, Schwabe MJ, et al. Survival after treatment of rabies with induction of coma. N Engl J Med 2005:352:2508-14.

[5] Hemachudha T, Sunsaneewitayakul B, Desudchit T, Suankratay C, Sittipunt C, Wacharapluesadee S, et al. Failure of therapeutic coma and ketamine for therapy of human rabies. J Neurovirol 2006;12:407-9.

[6] Jackson AC. Rabies: new insights into pathogenesis and treatment. Curr Opin Neurol 2006;19:267-70.

[7] Muller T, Dietzschold B, Ertl H, Fooks AR, Freuling C, Fehlner-Gardiner C, et al. Development of a mouse monoclonal antibody cocktail for post-exposure rabies prophylaxis in humans. PLoS Negl Trop Dis 2009;3:e542.

[8] Appolinario CM, Jackson AC. Antiviral therapy for human rabies. Antivir Ther 2015;20:1-10.

[9] De Benedictis P, Minola A, Rota Nodari E, Aiello R, Zecchin B, Salomoni A, et al. Development of broad-spectrum human monoclonal antibodies for rabies post-exposure prophylaxis. EMBO Mol Med 2016;8:407-21.

[10] Rinaldi AC. Antimicrobial peptides from amphibian skin: an expanding scenario. Curr Opin Chem Biol 2002;6:799-804.

[11] Neiva M, Vargas DC, Conceicao K, Radis-Baptista G, Assakura MT, Jared C, et al. Gene expression analysis by ESTs sequencing of the Brazilian frog Phyllomedusa nordestina skin glands. Toxicon: Official Journal of the International Society on Toxinology; 2013. p. 139-50.

[12] Mor A, Nicolas P. Isolation and structure of novel defensive peptides from frog skin. Eur J Biochem 1994:219:145-54.

[13] Mor A, Nguyen VH, Delfour A, Migliore-Samour D, Nicolas P. Isolation, amino acid sequence, and synthesis of dermaseptin, a novel antimicrobial peptide of amphibian skin. Biochemistry 1991;30:8824-30.

[14] Krugliak M, Feder R, Zolotarev VY, Gaidukov L, Dagan A, Ginsburg H, et al. Antimalarial activities of dermaseptin S4 derivatives. Antimicrob Agents Chemother 2000;44:2442-51. 
[15] Nicolas P, El Amri C. The dermaseptin superfamily: a gene-based combinatorial library of antimicrobial peptides. Biochim Biophys Acta 2009;1788:1537-50.

[16] Amiche M, Ladram A, Nicolas P. A consistent nomenclature of antimicrobial peptides isolated from frogs of the subfamily Phyllomedusinae. Peptides 2008;29:2074-82.

[17] Mor A, Nicolas P. The NH2-terminal alpha-helical domain 1-18 of dermaseptin is responsible for antimicrobial activity. J Biol Chem 1994;269:1934-9.

[18] Nicolas P, Mor A. Peptides as weapons against microorganisms in the chemical defense system of vertebrates. Annu Rev Microbiol 1995;49:277-304.

[19] Dathe M, Wieprecht T. Structural features of helical antimicrobial peptides: their potential to modulate activity on model membranes and biological cells. Biochim Biophys Acta 1999;1462:71-87.

[20] Epand RM, Vogel HJ. Diversity of antimicrobial peptides and their mechanisms of action. Biochim Biophys Acta 1999;1462:11-28.

[21] Shai Y. Mechanism of the binding, insertion and destabilization of phospholipid bilayer membranes by alpha-helical antimicrobial and cell non-selective membrane-lytic peptides. Biochim Biophys Acta 1999:1462:55-70.

[22] Tossi A, Sandri L, Giangaspero A. Amphipathic, alpha-helical antimicrobial peptides. Biopolymers 2000;55:4-30.

[23] Feder R, Dagan A, Mor A. Structure-activity relationship study of antimicrobial dermaseptin S4 showing the consequences of peptide oligomerization on selective cytotoxicity. J Biol Chem 2000;275:4230-8.

[24] Rotem S, Radzishevsky I, Mor A. Physicochemical properties that enhance discriminative antibacterial activity of short dermaseptin derivatives. Antimicrob Agents Chemother 2006;50:2666-72.

[25] Zairi A, Ferrieres L, Latour-Lambert P, Beloin C, Tangy F, Ghigo JM, et al. In vitro activities of dermaseptins K4S4 and K4K20S4 against Escherichia coli, Staphylococcus aureus, and Pseudomonas aeruginosa planktonic growth and biofilm formation. Antimicrob Agents Chemother 2014;58:2221-8.

[26] Efron L, Dagan A, Gaidukov L, Ginsburg H, Mor A. Direct interaction of dermaseptin S4 aminoheptanoyl derivative with intraerythrocytic malaria parasite leading to increased specific antiparasitic activity in culture. J Biol Chem 2002;277:24067-72.

[27] Brand GD, Leite JR, Silva LP, Albuquerque S, Prates MV, Azevedo RB, et al. Dermaseptins from Phyllomedusa oreades and Phyllomedusa distincta. AntiTrypanosoma cruzi activity without cytotoxicity to mammalian cells. J Biol Chem 2002;277:49332-40.

[28] Savoia D, Donalisio M, Civra A, Salvadori S, Guerrini R. In vitro activity of dermaseptin S1 derivatives against genital pathogens. Apmis 2010;118:674-80.

[29] Morton CO, Dos Santos SC, Coote P. An amphibian-derived, cationic, alphahelical antimicrobial peptide kills yeast by caspase-independent but AIFdependent programmed cell death. Mol Microbiol 2007;65:494-507.

[30] De Lucca AJ, Bland JM, Jacks TJ, Grimm C, Walsh TJ. Fungicidal and binding properties of the natural peptides cecropin B and dermaseptin. Med Mycol 1998:36:291-8.

[31] Pinto EG, Pimenta DC, Antoniazzi MM, Jared C, Tempone AG. Antimicrobial peptides isolated from Phyllomedusa nordestina (Amphibia) alter the permeability of plasma membrane of Leishmania and Trypanosoma cruzi. Exp Parasitol 2013;135:655-60.

[32] Chinchar VG, Bryan L, Silphadaung U, Noga E, Wade D, Rollins-Smith L. Inactivation of viruses infecting ectothermic animals by amphibian and piscine antimicrobial peptides. Virology 2004;323:268-75.

[33] Belaid A, Aouni M, Khelifa R, Trabelsi A, Jemmali M, Hani K. In vitro antiviral activity of dermaseptins against herpes simplex virus type 1. J Med Virol 2002;66:229-34.

[34] Bergaoui I, Zairi A, Tangy F, Aouni M, Selmi B, Hani K. In vitro antiviral activity of dermaseptin S(4) and derivatives from amphibian skin against herpes simplex virus type 2. J Med Virol 2013;85:272-81.

[35] Lorin C, Saidi H, Belaid A, Zairi A, Baleux F, Hocini H, et al. The antimicrobial peptide dermaseptin S4 inhibits HIV-1 infectivity in vitro. Virology 2005;334:264-75.

[36] Wang G, Watson KM, Peterkofsky A, Buckheit Jr RW. Identification of novel human immunodeficiency virus type 1-inhibitory peptides based on the antimicrobial peptide database. Antimicrob Agents Chemother 2010;54:1343-6.

[37] Sitaram N, Nagaraj R. Interaction of antimicrobial peptides with biological and model membranes: structural and charge requirements for activity. Biochim Biophys Acta 1999;1462:29-54.
[38] Jenssen H, Hamill P, Hancock RE. Peptide antimicrobial agents. Clin Microbiol Rev 2006;19:491-511.

[39] Ghosh JK, Shaool D, Guillaud P, Ciceron L, Mazier D, Kustanovich I, et al. Selective cytotoxicity of dermaseptin S3 toward intraerythrocytic Plasmodium falciparum and the underlying molecular basis. I Biol Chem 1997;272:31609-16.

[40] Lentz TL, Burrage TG, Smith AL, Crick J, Tignor GH. Is the acetylcholine receptor a rabies virus receptor? Science 1982;215:182-4.

[41] Thoulouze MI, Lafage M, Schachner M, Hartmann U, Cremer H, Lafon M. The neural cell adhesion molecule is a receptor for rabies virus. J Virol 1998;72:7181-90.

[42] Tuffereau C, Desmezieres E, Benejean J, Jallet C, Flamand A, Tordo N, et al, Interaction of lyssaviruses with the low-affinity nerve-growth factor receptor p75NTR. J Gen Virol 2001;82:2861-7.

[43] Sato M, Tanaka H, Yamada T, Yamamoto N. Persistent infection of BHK21/WI-2 cells with rubella virus and characterization of rubella variants. Arch Viro 1977;54:333-43.

[44] Smith JYP, Baer G. A rapid fluorescent focus inhibition test (RFFIT) for determining virus-neutralizing antibody. 4 ed. Geneva (Switzerland): World Health Organization; 1996.

[45] Duda Jr TF, Vanhoye D, Nicolas P. Roles of diversifying selection and coordinated evolution in the evolution of amphibian antimicrobial peptides. Mol Biol Evol. 2002;19:858-64.

[46] Kustanovich I, Shalev DE, Mikhlin M, Gaidukov L, Mor A. Structura requirements for potent versus selective cytotoxicity for antimicrobial dermaseptin S4 derivatives. J Biol Chem 2002;277:16941-51.

[47] Galanth C, Abbassi F, Lequin O, Ayala-Sanmartin J, Ladram A, Nicolas P, et al Mechanism of antibacterial action of dermaseptin B2: interplay between helix-hinge-helix structure and membrane curvature strain. Biochemistry 2009;48:313-27.

[48] Shalev DE, Rotem S, Fish A, Mor A. Consequences of N-acylation on structure and membrane binding properties of dermaseptin derivative K4-S4-(1-13). Biol Chem 2006;281:9432-8.

[49] Radzishevsky IS, Rotem S, Bourdetsky D, Navon-Venezia S, Carmeli Y, Mor A Improved antimicrobial peptides based on acyl-lysine oligomers. Nat Biotechnol 2007;25:657-9.

[50] Marynka K, Rotem S, Portnaya I, Cogan U, Mor A. In vitro discriminative antipseudomonal properties resulting from acyl substitution of N-terminal sequence of dermaseptin s4 derivatives. Chem Biol 2007;14:75-85.

[51] Pouny Y, Rapaport D, Mor A, Nicolas P, Shai Y. Interaction of antimicrobia dermaseptin and its fluorescently labeled analogues with phospholipid membranes. Biochemistry 1992;31:12416-23.

[52] Matsuzaki K, Sugishita K, Ishibe N, Ueha M, Nakata S, Miyajima K, et al. Relationship of membrane curvature to the formation of pores by magainin 2 . Biochemistry 1998;37:11856-63.

[53] Huang HW. Action of antimicrobial peptides: two-state model. Biochemistry 2000;39:8347-52.

[54] Shai Y. Mode of action of membrane active antimicrobial peptides. Biopolymers 2002;66:236-48.

[55] Bechinger B, Lohner K. Detergent-like actions of linear amphipathic cationic antimicrobial peptides. Biochim Biophys Acta 2006;1758:1529-39.

[56] Duclohier H. How do channel- and pore-forming helical peptides interact with lipid membranes and how does this account for their antimicrobial activity? Mini Rev Med Chem 2002;2:331-42.

[57] Aisenbrey C, Bechinger B, Grobner G. Macromolecular crowding at membrane interfaces: adsorption and alignment of membrane peptides. J Mol Bio 2008;375:376-85.

[58] Leite JR, Brand GD, Silva LP, Kuckelhaus SA, Bento WR, Araujo AL, et al Dermaseptins from Phyllomedusa oreades and Phyllomedusa distincta: secondary structure, antimicrobial activity, and mammalian cell toxicity. Comp Biochem Physiol A Mol Integr Physiol 2008;151:336-43.

[59] Jean-Francois F, Elezgaray J, Berson P, Vacher P, Dufourc EJ. Pore formation induced by an antimicrobial peptide: electrostatic effects. Biophys J 2008;95:5748-56

[60] Perez-Cordero JJ, Lozano JM, Cortes J, Delgado G. Leishmanicidal activity of synthetic antimicrobial peptides in an infection model with human dendritic cells. Peptides 2011;32:683-90.

[61] Hemachudha T, Laothamatas J, Rupprecht CE. Human rabies: a disease of complex neuropathogenetic mechanisms and diagnostic challenges. Lancet Neurol 2002;1:101-9. 